\title{
Editorial
}

\section{US regulatory reform}

Journal of Banking Regulation (2009) 11, 1-5. doi:10.1057/jbr.2009.17

The new Treasury Secretary Timothy Geithner published the Obama Administration's proposals for Financial Regulatory Reform based on $A$ New Foundation on 17 June 2009. ${ }^{1}$ This follows Hank Paulson's earlier package of recommendations in 2008. While many had hoped for a substantial restructuring of the complex regulatory system in the United States, the institutional reforms announced were limited. The Office of Thrift Supervision (OTS) was merged with the Office of the Comptroller of the Currency (OCC) to create a new National Bank Supervisor (NBS) within the Treasury with a separate Office of National Insurance (ONI) being set up within the Treasury. No attempt was made to merge the Securities and Exchange Commission (SEC) and Commodity Futures Trading Commission (CFTC) with the existing roles of the Federal Deposit Insurance Corporation (FDIC) and National Credit Union Administration (NCUA) being retained and that of the Federal Reserve strengthened as the systemic supervisor.

Two new agencies were created with a Financial Services Oversight Council (FSOC) to oversee systemic supervision and a separate Consumer Financial Protection Agency (CFPA) to monitor consumer products including mortgages and credit cards. Rather than simplify, the proposals may only further complicate the US regulatory structure. ${ }^{2}$ While the Obama Administration had originally proposed more substantial reform, Geithner had to accept the strength of the opposition on Capitol Hill. ${ }^{3}$

The Financial Regulatory Reform paper accepts that the crisis had many causes and went back decades. Financial intermediaries and investors had become complacent after years without a serious economic recession. ${ }^{4}$ It was also admitted that the government could have done more to prevent many of the problems and the resulting financial instability. ${ }^{5}$ The authorities were concerned to attempt to restore confidence in the integrity of the financial system and to build a new foundation for financial regulation based on five key objectives of improved oversight and control of financial firms and financial markets, consumer protection, financial crisis management and international cooperation.

Each of these objectives is considered further below.

\section{IMPROVED SUPERVISION AND REGULATION OF FINANCIAL FIRMS}

The system had been unable to deal with the crisis that arose following a credit boom and housing bubble and then significant de-leveraging and credit contraction. ${ }^{6}$ The system for the supervision and regulation of financial firms had to be made more robust with a number of entities that posed a significant risk to the financial system being unregulated or poorly regulated. The new FSOC would be created $^{7}$ with the Federal Reserve being given additional authority to oversee the activities of any systemically sensitive firm (referred to as a 'tier 1 Financial Holding Company' (FHC)). ${ }^{8}$ Higher capital and other prudential standards would be imposed on all banks and bank holding companies. ${ }^{9}$ A new 
NBS would be established to supervise all federally chartered banks with the abolition of the separate Federal Thrift Charters provided by the OTS. ${ }^{10}$ Investment banks would be subject to the consolidated supervision of the Federal Reserve with SEC authority in this regard being withdrawn. ${ }^{11}$ Hedge funds and other private capital pools would have to register with the SEC under the Investment Advisors Act with the SEC's regulation of money market mutual funds (MMFs) being strengthened. ${ }^{12}$ A new ONI would be set up to coordinate insurance regulation with the activities of Government Sponsored Enterprises (GSEs), including Fannie Mae and Freddy Mac and the Federal Home Loan Bank system being subject to review. ${ }^{13}$

\section{REGULATION OF FINANCIAL MARKETS}

Financial innovation and the development of new instruments, including in connection with securitisation and OTC derivatives, was intended to distribute risk to reduce systemic exposure, promote efficiency and better allocate resources. Risk was nevertheless often concentrated in opaque and complex ways with risk management not being able to keep up with the financial innovation that had occurred. ${ }^{14}$ Securitisation would then be subject to strengthened regulation including with regard to transparency, credit ratings and retained capital charges. ${ }^{15}$ OTC derivatives including credit default swaps would be subject to federal regulation. ${ }^{16}$ The SEC and CFTC would issue recommendations to harmonise the regulation of securities and futures markets. The Federal Reserve would be given new responsibility for the oversight of systemically important payment, clearing and settlement systems including through the provision of access to its discount window.

\section{CONSUMER PROTECTION}

Consumer protection and education had been the responsibility of a number of federal and state agencies before the crisis with significant gaps and weaknesses arising within the system. Unregulated mortgage brokers had, in particular, taken advantage of specific regulatory gaps to the disadvantage of unsuspecting borrowers in many cases. The new proposals were designed to promote transparency, simplicity, fairness, accountability and access and in so doing rebuild trust in the financial markets. A new CFPA would be established to prevent consumers against unfair, deceptive and abusive practices. ${ }^{17}$ The CFPA would be an independent agency with appropriate funding and a wide jurisdiction and have sole authority for rule making under consumer financial protection statutes. The CFPA would be responsible for supervisory and enforcement actions including the coordination of enforcement efforts at the state level. The role of the Federal Trade Commission would also be strengthened in connection with consumer protection matters. The role and function of the SEC in protecting investors would also be strengthened with a separate Financial Consumer Co-ordinating Council (FCCC) being set up to coordinate federal and state consumer protection activities.

\section{FINANCIAL CRISIS}

The crisis had revealed that the only available means for managing a large financial institution in severe distress was either through emergency funding, as with American International Group, Inc (AIG), or bankruptcy, as with Lehman Brothers. This was considered to have revealed a significant gap in the US regulatory system. It was accordingly proposed that a new special resolution regime be created for the management of distressed Bank Holding Companies (BHCs) and tier 1 FHCs. This would be modelled on the FDIC's resolution regime for insured depository institutions and provide a supplementary set of options. Section 13(3) of the Federal Reserve Act would be amended to require the prior written approval of the Secretary of the Treasury for any 
extensions of credit by the Federal Reserve to individuals, partnerships or corporations in 'unusual and exigent circumstances'. While the Federal Reserve had used this power on a number of occasions during the crisis, it had in each case sought prior Treasury approval. The amendment simply formalises this relationship.

\section{INTERNATIONAL COOPERATION}

The Administration accepted that the systemic risk the global financial system may be intensified if and when financial institutions sought to take advantage of regulatory arbitrage and move to jurisdictions with less strict controls. The United States would accordingly attempt to undertake a leadership role in coordinating financial policy especially through the G20, the Financial Stability Board (FSB) and the Basel Committee on Banking Supervision. This would include implementation of the eight-part declaration on financial regulatory reform contained in the April 2009 G20 London Summit statement. This principally related to strengthening international capital standards, ${ }^{18}$ improving the oversight of global financial markets, ${ }^{19}$ improving the supervision of internationally active financial firms ${ }^{20}$ and improving crisis prevention and management. ${ }^{21}$ Further recommendations were made with regard to strengthening the restructuring and operations of the FSB, improving liquidity standards, clarifying the definition and application of tier 1 FHCs to foreign firms, improving compensation practices, promoting improved standards in prudential regulation, money laundering and anti-terrorist financing and information exchange of taxation at the same time as improving fair value accounting standards (including the impairment of financial instruments). The oversight of credit rating agencies should also be strengthened at the international level.

\section{REGULATORY COMMENTS}

The stated objective of the US proposals was to create a new foundation for financial regulation and specifically one that was simpler and more effectively enforced. The structural foundations of the new regime would appear to be largely in tact (apart from with the loss of the OTS). A new NBS (with the OCC and OTS) and ONI have been set up in addition to the larger FSOC and CFPA and separate FCCC. The system can only be considered to be more relevant and less complex. ${ }^{22}$ The actual role and function of all of these agencies will also depend upon the final legislation enacted following Congressional dispute, haggling and compromise. The success of the institutional initiatives announced may ultimately in practice depend upon the personalities of the senior officials concerned. ${ }^{23}$

Almost all of the regulatory reforms simply reflect announcements made elsewhere, such as with regard to strengthening capital, liquidity and other prudential standards, although again almost all of this depends upon further work and final regulatory or legislative amendment. Procyclicality is mentioned but not stressed as in other reform packages such as in the UK. Extending regulatory oversight to include hedge funds and other capital pools was politically necessary although again this only amounts to a registration rather than full regulatory obligation with managers already being separately controlled by the SEC. The provisions on strengthening the oversight of credit rating agencies are similarly dilute. The relationship between the Treasury and Federal Reserve in connection with crisis management is confirmed with an extended resolution regime created for non-bank entities although this will simply parallel the existing FDIC arrangements. The international recommendations are again modest but predictable. The most substantial operational reforms may then take place in the area of consumer protection following the creation of the CFPA and proposed new FCCC. The UK FSA would appear to have taken a much more substantial lead in this area than in the United States. These are necessary changes although it remains to be seen how long it takes to 
establish an effective federal consumer agency. Much of this will depend upon how quickly the new entity can establish its authority and the cooperation it is able to obtain from the other state and federal agencies involved.

In systemic terms, the US recommendations may be considered to represent a functional compromise. They are nevertheless still based on the assignment of core systemic responsibility to the Federal Reserve as central bank with the new Council acting more in an advisory and oversight manner. Much of this will then again depend upon the cooperation, goodwill and support of the other agencies concerned which cannot simply be assumed. While this does, at least, clarify the allocation of systemic responsibility, no guidance or direction has yet been provided on the meaning, structure and content of the new macroprudential oversight regime to be set up. This has simply to have been left to the Federal Reserve to resolve and determine over time. The success of the initiative will then depend upon the ability of the Federal Reserve to develop a meaningful and insightful new regime and package of supporting measures in this sensitive but complex and difficult area.

\section{REFERENCES AND NOTES}

1 Department of the Treasury. (2009) Financial Regulatory Reform. A New Foundation: Rebuilding Financial Supervision and Regulation. Washington, DC: Department of the Treasury.

2 One financial lobbyist was reported to have described the reforms as being too 'balkanise the Balkans'. Luce, E. (2009) New recipe thickens alphabet soup. Financial Times, 12 June: 6.

3 Richard Shelby, Senior Republican member of the Senate Banking Committee, stated that 'There are powerful forces at work that want to preserve the existing system' and 'They want to do everything they can to keep things the way they are'. Scott Talbott, Financial Services Roundtable, reported that the US financial sector was 'mostly happy' with the proposals with the principal objection being with regard to the creation of the new consumer regulatory agency. Barney Frank, Chairman of the House Financial Services Committee, and Collin Peterson, Chairman of the House Agricultural Committee, did not want the merger of the SEC and CFTC, which they separately monitor (Financial Times, columns 3, 4 and 6) $)^{2}$. See also Braithwaite, T. Plan for systemic risks set to end up a fudge. Financial Times, 12 June: 6 , column 8
4 The report refers to a number of market failings: (a) 'exaggerated expectations' about the resilience of US financial markets and firms arose as earlier crises including Long Term Capital Management (LTCM) and Asia had little impact on US economic growth; (b) rising asset prices including housing concealed weak credit underwriting standards and growing leverage; (c) risk management systems within the largest firms failed to deal? with the complexity of new products; (d) underwriting standards were weakened through lack of transparency and standards in loan markets; (e) market discipline failed as investors relied excessively on credit rating agencies; (f) remuneration practices rewarded short-term profits as against long-term value; and $(\mathrm{g})$ increased access to credit by households was undermined by 'pervasive failures' in consumer protection with many Americans acquiring obligations that they could not understand and could not afford (see note 2).

5 (a) The government was unable to monitor, prevent and deal with risks through gaps and weaknesses in the supervision and regulation of financial firms; (b) no agency was responsible for protecting the economy and financial system as a whole; (c) bank holding company regulation had focused on the protection of the subsidiary bank and not the firm as a whole; (d) investment banks were able to avoid leverage rules by switching regulators; (e) any depository owners, such as AIG, avoided holding company regulation where their subsidiaries were technically defined as banks (ibid.).

6 Most of the largest firms had been regulated although: (a) capital and liquidity requirements were too low; (b) regulators failed to consider the impact of the failure of large, interconnected and highly leveraged institutions; (c) the supervision of the consolidated operations of large financial groups had been divided among several agencies; (d) investment firms were inadequately supervised while the fragility of money market mutual firms was not accepted and hedge funds and other private capital pools avoided regulation (see note 5).

7 The purpose of the FSOC was to facilitate information sharing and coordination, identify emerging risks, advise the Federal Reserve on the identification of systemically important firms in terms of size, leverage and relations and act as a forum for resolving jurisdictional disputes between member agencies. Meetings of the FSOC would be chaired by the Treasury with members consisting of the chairmen and directors of the Federal Reserve, the new NBS, CFPA, SEC, CFTC, FDIC and Federal Housing Finance Agency (FHFA). The Council would be supported by a permanent, full-time secretariat based in the Treasury. The Council would be given statutory power to collect information from any financial firm and refer any emerging risk identified to the relevant authority.

8 All tier 1 FHCs would be subject to consolidated supervision and regulation by the Federal Reserve Board. Criteria would be issued to identify relevant tier 1 FHCs with heightened prudential standards including capital, liquidity and risk management being applied. All US and foreign parent and subsidiary companies would be subject to consolidation. Although depository institution subsidiaries would continue to be operationally regulated by their own authority, previous restrictions under the Gramm-Leach 
Bliley Act on the ability of the Federal Reserve to obtain reports or impose directions would be removed. Consolidated tier 1 EHC supervision would be conducted on a macro-prudential basis.

9 Treasury working groups would produce recommendations for the imposition of higher capital standards for banks, BHCs and tier 1 FHCs and improved supervision of banks and BHCs. FHCs would be required to comply with all relevant capital and management requirements on a consolidated basis. Standards and guidelines would be issued to align remuneration practices with long-term shareholder value and prevent any threats to the safety and soundness of supervised institutions. Revised forward-looking loan loss provisioning practices providing a wider range of available credit information would be prepared by relevant accounting standards setters including the FASB, IASB and SEC. Strengthened firewalls would also be established between banks and their affiliates to limit the spread of federal safety net benefits.

10 The supervision of all federally chartered depository institutions and federal branches and agencies of foreign banks would be transferred to the NBS. Federal thrift charters would be abolished, although interstate branching rules would be maintained for state and national banks. The separation of banking and commerce would be strengthened with all companies controlling an insured depository institution being subject to federal consolidated supervision and subject to the non-banking activity restrictions in the BHC Act. BHC loopholes would be closed for thrift holding companies, industrial loan companies, credit card banks, trust companies and grandfathered 'non-bank' banks.

11 The SEC would end its 'Consolidated Supervised Entity Program' (CSEP) and 'Supervised Investment Bank Holding Company Program'. The SEC had been the holding company supervisor of Lehman Brothers and Bear Stearns under the CSEP

12 A separate report on the future regulation of MMFs would be prepared by the President's Working Group of Financial Markets, in particular, to remove the risk of runs.

13 The function of the ONI would be to gather information, develop expertise, negotiate international agreements and coordinate insurance sector policy. Recommendations for the future treatment of GSEs would be prepared by the Treasury with the Department of Housing and Urban Development in consultation with other relevant agencies.

14 Securitisation had specifically created conflicts of interest that market discipline had failed to correct. Loan originators did not obtain adequate documentation on income and ability to pay with underwriting standards dropping and securitisers failing to apply proper standards in the purchase of loans. Investors become over-reliant on credit rating agencies with agencies failing to describe exposures accurately and with transparency preventing market participants from understanding the full nature of the risks acquired (see note 6).

15 Regulations would be issued requiring originators and sponsors to retain an economic interest in a material portion of the credit risk of all securitised credit exposures. Compensation structures would be aligned with the longerterm performance of underlying loans. The SEC would continue to increase transparency and standardisation within securitisation markets and strengthen its regulation of credit rating agencies including through the promotion of policies and procedures to manage and disclose conflicts of interest and differentiate between structured and other products. Regulators would also attempt to reduce their use of credit ratings in regulations and supervisory practices insofar as possible.

16 Regulations would be issued to prevent activities in OTC markets from threatening the stability of the financial system, promoting efficiency and transparency, preventing market manipulation, fraud and other market abuses and ensuring that OTC derivatives were not marketed inappropriately to unsophisticated parties.

17 The CFPA would be set up as a single primary federal agency to protect consumers of credit, savings, payment and other consumer financial products and services and to regulate the providers of such products and services.

18 The Basel Committee should continue to improve Basel II by refining relevant risk weights applicable to the trading book and securitisation products, create a supplemental leverage ratio and improve the definition of capital by the end of 2009, at the same time as conduct a separate review into limiting the procyclical effects of the Basel II framework.

19 Credit derivative and other OTC markets should be subject to standardisation and improved oversight including through the use of central counterparties.

20 International cooperation on the supervision of global financial firms should be strengthened through the establishment and operational development of supervisory colleges through the FSB and other national agencies.

21 The Basel Committee should expedite its work on improving the cross-border resolution of global financial firms with information sharing arrangements being improved and implementation of the FSB principles on crossborder crisis management.

22 Financial Times. (2009) Complexity has led to cracks in system. 12 June, p. 6.

23 It was, for example, reported that Sheila Bair, Chairman of the FDIC, was anxious to strengthen the FDIC's role in the new systemic arrangements created. See, for example, Financial Times. (2009) Bair lobbies for strong position. 12 June, p. 6, column 6 .

G.A. Walker

Queen Mary, University of London, UK 